\title{
CITRUS RIMAU GERGA LEBONG (Citrus reticulata) FARMERS SATISFACTION TO THEIR MARKETING AGENCY SERVICES IN REJANG LEBONG DISTRICT
}

\author{
Emlan Fauzi' ${ }^{1}$ Ketut Sukiyono², M. Zulkarnain Yuliarso² \\ 1)Study Program of Agribusiness Magister Faculty of Agriculture, University of Bengkulu \\ 2) Department of Agricultural Socio-Economics, Faculty of Agriculture, University of \\ Bengkulu \\ Email: 1) emlan.81@gmail.com; 2) ksukiyono@unib.ac.id
}

How to Cite :

Fauzi, E., K Sukiyono, M Z Yuliarso, 2020. Satification Citrus Farmers to Their Marketing Instistutional Services in Rejang Lebong District. Journal of Agri Socio-Economics and Business. 2 (1): 01-14 DOI: https://doi.org /10.31186/jaseb.2.1.01-14

\section{ARTICLE HISTORY}

Received [2020-03-16]

Revised [2020-05-11]

Accepted [2020-05-17]

\section{KEYWORDS}

satisfaction, marketing services citrus,
This is an open access article under the $C C-B Y-S A$ license

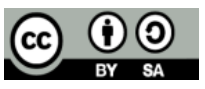

\section{ABSTRACT}

The existence of RGL Citrus marketing institutions is very important for the development of RGL Citrus agribusiness from the marketing aspect. The services of a marketing agency are divided into several dimensions, each of which has service attribute items. This study aims to: (1) analyze the level of marketing institutional performance in $R G L$ Citrus farming (2) analyze the level of farmer satisfaction with marketing institutional performance in RGL Citrus farming and (3) analyze the factors that influence the level of farmer satisfaction with marketing institutional performance in RGL Citrus farming in Bermani Ulu Raya District, Rejang Lebong Regency. The study was conducted in May to October 2019 in Bermani Ulu Raya District, Rejang Lebong Regency. Census data collection of 117 RGL citrus farmers. Data were analyzed with Importance Performance Analysis (IPA), Customer Satisfaction Index (CSI) and multinomial logistic regression. The results showed the marketing institutional performance was good. The quality of service that needs to be improved is the dimension of trustworthiness, assurance, direct evidence and empathy and responsiveness. The level of satisfaction of RGL citrus farmers to their marketing institutions is in the satisfied category (73.58\%). The factor that significantly influences satisfaction on marketing institutions is price suitability. 


\section{INTRODUCTION}

Citrus is one of national strategic commodities In Indonesia. Until now the needs of Citruss in indonesia still cannot be met from domestic production. The consumption of Citruss in Indonesia in 2015 is around $3.28 \mathrm{kgs} /$ capita. Indonesia still lacks Citrus production of 235 thousand tons in 2015 and still imports 106 thousand tons with a value of 141 million US Dollars (around 2 trillion rupiahs). This value is quite large absorbing the country's foreign exchange.

The Ministry of Agriculture (MoA), seeks to increase national citrus production through several policies, one of which is the development of a national agricultural area as stipulated in the MoA rules number 672/2018 on the Location of National Agricultural Areas. In Bengkulu Province the location of the national agricultural development area is spread over 9 (nine) districts covering 14 strategic commodities. One of the strategic commodities is citrus. Citrus development in Bengkulu Province is very potential, especially RGL citrus. RGL is an abbreviation of Rimau Gerga Lebong, or better known as grapefruit. RGL Citruss have a competitive advantage, namely yellow-Citrus fruit, fruit throughout the year, large fruit size of 200-350 grams and have good market potential (Suwantoro 2010). The area of RGL citrus plantations in Rejang Lebong Regency is estimated to be around 300 hectares spread over five districts with the largest area located in Bermani Ulu Raya District which is around 240 hectares with the main center in Pal VII Village.

RGL citrus agribusiness in Bermani Ulu Raya District is supported by agency. The role of marketing institutions is crucial to the success of RGL Citrus farming. On the other hand farmers still feel their bargaining power is still low compared to the bargaining power of traders. Determination of fruit size (grading) is determined entirely by traders, so farmers found it difficult to get the price of RGL citrus fruits included in grade A (Rp. 15,000), besides that the accuracy in payment is still not good. Eventhough they complain about the condition, farmers still keep in touch with marketing agency and hope that their services will change for the better. So that it will affect farmers' perceptions of the performance of marketing institutions.

The performance of marketing institutions is largely determined by their services quality. The services of the RGL Citrus marketing agency are divided into several dimensions, each of which has service attribute items (Parasuraman et al, 1985). These attributes are assessed by RGL Citrus farmers to see the level of satisfaction that begins with the identification of the performance and interests of each attribute. The level of satisfaction of RGL citrus farmers is not only determined by their performance and interests, but the satisfaction of RGL citrus farmers can be influenced by various factors such as farmers' internal factors and external factors.

There are several ways to measure service quality, one way to measure service quality is to apply the Importance Performance Analysis method (Kumar et al, 2009, Tedjaningsih et al, 2018, and Gama et al, 2016). The analytical method used is quadrant analysis (Sa'adah et al, 2019). This quadrant analysis is used to determine consumer responses to attributes plotted based on the level of importance and 
performance of each of these attributes (Diyahya et al, 2016). Based on this quadrant analysis, it can then be seen the location of each variable is in a different quadrant, so it can be seen what variables need to be improved and get more attention. Then Aritonang (2005) states to measure overall customer satisfaction can be measured using the Customer Satisfaction Index (CSI). Furthermore Fitriana et al (2014); Gama et al (2016); Widyastuti and Widiastuti (2014); Utomo and Nurmalina (2011); and Sa'adah et al (2019) Customer Satisfaction Index is needed because the process of measuring customer satisfaction is continuous.

Therefore, this study aims to: (1) analyze the level of performance of marketing institutions in RGL Citrus farming, (2) analyze the level of satisfaction of RGL citrus farmers on marketing institutional performance and (3) analyze the factors that influence the satisfaction level of RGL citrus farmers on the performance of marketing institutions in Bermani Ulu Raya District, Rejang Lebong Regency.

\section{RESEARCH METHODS}

\section{Place and time of research}

This research was conducted in Bermani Ulu Raya District, Rejang Lebong Regency and carried out in the span of May - October 2019. Determination of the location was done purposive with consideration that the District of Bermani Ulu Raya was the most extensive area of RGL Citrus development area (240 ha).

\section{Sample Determination Method}

The object of this research is farmers who cultivate RGL citruss and are served by marketing institutions. Sampling was done by census for all RGL citrus farmers in the Citrus development center in Bermani Ulu Raya District as many as 117 people.

\section{Collecting Data Method}

This research uses primary data and secondary data. Primary data is data obtained from the first source either from individuals or individuals such as the results of interviews or the results of questionnaires that are usually done by researchers (Umar, 2003 in Listiawati, 2010). Primary data in this study are data obtained from census results. Information about citrus agribusiness in the Rejang Lebong district was also obtained from key informants namely field officers, head of farmer groups, and citrus traders. In addition to primary data, secondary data from official / agency reports, statistical reports and literature related to the research topic were also collected. 


\section{Data Analysis Method}

\section{Importance and Performance Analysis (IPA)}

Analysis of the level of importance and performance of customer satisfaction is described in the Cartesian diagram (Martilla and James, 1977) based on farmers' responses to the service quality of marketing agency. According to Tjiptono et al. (2011), the stages of IPA calculation are carried out as follows:

1. Weighting the importance and performance assessment for each attribute by using a Likert scale that is very important / very good is given a weight of 5 , important / good is given a weight of 4, quite important / good enough is given a weight of 3, not important / not good is given a weight of 2 and very not important / not very good given a weight of 1 .

2. Calculate the average importance and performance assessment for each attribute using the formula:

$$
\overline{\mathrm{X}}=\frac{\sum_{\mathrm{i}-1}^{\mathrm{k}} \mathrm{Xi}}{\mathrm{n}} \text { and } \overline{\mathrm{Yi}}=\frac{\sum_{\mathrm{i}=1}^{\mathrm{k}} \mathrm{Yi}}{\mathrm{n}}
$$

Where:

$\overline{X i}=$ weight of the average level of performance rating of $i$ th;

$\bar{Y} i=$ weight of the average level of importance assessment of $i^{\text {th }}$

$\mathrm{n}=$ number of respondents

3. Calculate the Level of Conformity (TKi) between the level of performance and interests or expectations. TKi is calculated by the following formula:

$$
\mathrm{TKi}=\frac{\overline{\mathrm{Xi}}}{\overline{\mathrm{Y}}} \times 100 \%
$$

Where: TKi = level of suitability

4. Calculate the average level of importance and performance for all attributes using the formula:

$$
\overline{\bar{X}}=\frac{\sum_{i=1}^{k} \overline{X i}}{n} \quad \text { and } \quad \overline{\bar{Y} i}=\frac{\sum_{i=1}^{k} \overline{Y i}}{n}
$$

Where:

$\overline{\bar{X}} \mathbf{i}=$ Weight of the average level of performance rating of the $i$ attribute

$\overline{\bar{Y}} i=$ Weight of the average level of importance assessment of the $i$ attribute

$\mathrm{n}$ = number of attribute

5. After the performance weights and importance of attributes are obtained, these values are plotted into a Cartesian diagram using the SPSS program. 


\begin{tabular}{c|c}
$\begin{array}{c}\text { Quadrant 1 } \\
\text { Concentrate Here }\end{array}$ & $\begin{array}{c}\text { Quadrant 2 } \\
\text { Keep Up The Good } \\
\text { Work }\end{array}$ \\
\hline Quadrant 3 \\
Low Priority & Quadrant 4 \\
Possibly Overkill
\end{tabular}

Picture 1

Quadrant Importance-Performance Analysis (Martilla and James, 1977)

\section{Analysis of Customer Satisfaction Index (CSI)}

The measurement method of CSI includes the following stages: (1) determining the Mean Importance Score (MIS) and Mean Satisfaction Score (MSS), (2) creating a weight factor (WF), (3) make a weighting score (WS), (4) determine CSI, the CSI formula (Widodo and Sutopo, 2018) is:

$$
\mathrm{CSI}=\frac{\mathrm{WT}}{5} \times 100 \%
$$

(5) CSI scores in this study were divided into 3 categories (less satisfied, satisfied and very satisfied) using standard deviations. The criteria for their authority are: (a) CSI values below standard deviation = unsatisfied, (b) CSI values within the standard deviation range $=$ satisfied, and (c) CSI values above the standard deviation = very satisfied.

\section{Analysis of Factors Affecting Farmer Satisfaction}

Factors that are suspected to affect the satisfaction of RGL citrus farmers to production input institutions are age (AGE), number of family dependents (FN), formal education (EDU), experience (EXP), (Sangadji and Sopiah, 2013; Widyasari et al, 2014), area of citrus land (LAND), and price (PRC) as dummy variable. Satisfaction $(Y)$ is divided into three categories, namely $Y=0$ when satisfied (within the range of standard deviations, $Y=1$ if unsatisfied (below the standard deviation value), $Y=2$ if very satisfied (above the standard deviation value). free $(Y)$ is a probability or chance of satisfaction that is influenced by the independent variable $(\mathrm{Xi})$, then the transformation is done with natural logarithms (Sriliana, 2012), so that it becomes:

$$
Y i=\ln \frac{P(X i)}{1-P(X i)} b o+b 1 \text { Age }+b 2 F N+b 3 E d u+b 4 E x p+b 5 \text { Land + b6PRC (D1) +e }
$$

$P(X i)$ is the satisfaction of RGL citrus farmers to the performance of their marketing institutions. To see whether each independent variable influences the dependent variable, the Wald test or Z-stat test in logistic regression is used (Subekti, 2014). 


\section{RESULTS AND DISCUSSION}

\section{Characteristics of the RGL Citrus Marketing Agency and The Fa rmers}

RGL Citrus market players in Rejang Lebong Regency consist of farmers as producers, retailers from within the sub-district, traders from inside the sub-district, and traders from outside the sub-district. Collector traders are still limited and there is no large-scale collector traders because citrus yields are still relatively small. RGL Citrus market from Rejang Lebong Regency is inside and outside the provinces. Marketing outside the provinces (Jakarta, Bogor, Jambi, Pekanbaru) is carried out by collectors from outside the subdistrict, while marketing to relatively close market locations (many cities) is carried out by collecting traders and retailers in the subdistrict . The ability of traders from outside the sub-district is only around 5-6 tons per 2 weeks. This condition indicates that the citrus agribusiness in Bermani Ulu Raya District is still very likely to be improved.

Farmers who cultivate RGL Citruss in Bermani Ulu Raya District have a very wide age range between 19-72 years with an average of 38.42 years. This indicates that citrus cultivation appeals to all levels of age of farmers both productive and unproductive ages. Productive age is the population aged between 15-64 years (Rusli, 2012). The average formal education level of RGL Citrus farmers in Bermani Ulu Raya District is 9.80 years (Junior High School), relatively better than the education level of national and provincial average farmers. The average level of formal education of the productive age population in Bengkulu Province in 2015 was 8.29 years or only reached the 2 nd grade of junior high school (Sudarwati, 2016). The number of workers from within the farmers family is very limited to manage their garden (an average of 0.99 ha approximately) causing farmers to have relatively large capital to pay labor costs. Citrus is the plant should be cultivated intensively that need labors and production facilities relative highly. Citrus farmers in Bermani Ulu Raya sub-district have a strong desire to develop RGL citrus farming based on the characteristics of farmers' age and land area. However, this desire to develop citrus needs to be accompanied by strengthening the performance of marketing agency at the farm level to strengthen the bargaining position of farmers in the RGL citrus agribusiness system. Good marketing institutional performance will increasing the satisfaction of farmers in the RGL Citrus business.

\section{Importance and Performance Analysis}

The level of appropriateness between performance and interests is obtained from the results of the comparison of performance and interests in each variable (Ramadhani et al, 2014). To find out the level of performance and level of importance of marketing institutions, it is first necessary to add up the entire score of the farmers' answers per each attribute. Calculation of performance level and importance evaluation can be seen in Table 1. 
Table 1. Results of Calculation of Average Rating of Performance Level and Interest of Marketing Institutions.

\begin{tabular}{llccc}
\hline & Service atrbutes & $\bar{X}$ & $\bar{Y}$ & TKi \\
\hline & Reliability & 3.70 & 4.07 & 90.73 \\
\hline 1 & Delivering citrus quality information & 3.58 & 4.04 & 88.58 \\
2 & Communication skills of traders & 3.93 & 4.04 & 97.25 \\
3 & Weighing Accuracy & 3.57 & 4.14 & 86.36 \\
\hline & Responsiveness & 3.63 & 3.90 & 93.23 \\
\hline 4 & Fast, precise and responsive service & 3.55 & 3.68 & 96.51 \\
5 & good service & 3.75 & 4.00 & 93.80 \\
6 & Seriously serving & 3.60 & 4.03 & 89.38 \\
\hline & Emphaty & 3.62 & 3.93 & 92.00 \\
\hline 7 & Willingness to prioritize farmers & 3.64 & 3.77 & 96.60 \\
8 & Prioritize subscribed farmers & 3.57 & 4.06 & 88,00 \\
9 & Help provide a solution & 3.63 & 3.97 & 91.40 \\
\hline & Assurance & 3.54 & 4.16 & 85.35 \\
\hline 10 & Prices received accordingly & 3.88 & 4.17 & 93.03 \\
11 & Timely Paying & 2.90 & 4.23 & 68.48 \\
12 & Openness and honesty of service & 3.85 & 4.07 & 94.54 \\
\hline & Tangibles & 3.93 & 4.05 & 96.98 \\
\hline 13 & Transportation tools & 3.92 & 4.04 & 97.04 \\
14 & Communication tools & 3.92 & 4.05 & 96.84 \\
15 & Transaction equipment & 3.94 & 4.06 & 97.05 \\
16 & Means of packing & 3.64 & 4.03 & 90.45 \\
\hline & & 3.68 & 4.02 & 91.58 \\
\hline
\end{tabular}

Source: Primary data, 2019

Overall the level of performance of the attributes is relatively smaller than the level of importance with an average percentage of conformity level of $91.58 \%$. This value indicates that what is done by the marketing agency is in accordance with what is desired by RGL Citrus farmers. If the conformity percentage is above $80 \%$, then the performance has met expectations (Siyamto, 2015; Diyahya et al, 2016; Indriwinangsih and Sudaryanto, 2007; Sukardi and Cholidis, 2006). Although the suitability between importance and performance is good, it is still necessary to improve the performance of the quality attributes services.

Timeliness of traders in paying the yields of RGL citrus farmers is still not in accordance with farmers' expectations so there needs to be improvement and attention from traders. The attribute that has the highest value is the communication ability of the merchant by $97.25 \%$. This attribute indicates that the merchant's communication skills are valued by RGL Citrus farmers and are considered to be very in line with their expectations, but they still need to be considered and maintained by the traders' communication skills. Measurement of the level of importance and performance of marketing institutions will be more easily understood by using a Cartesian diagram as presented in Figure 1. 


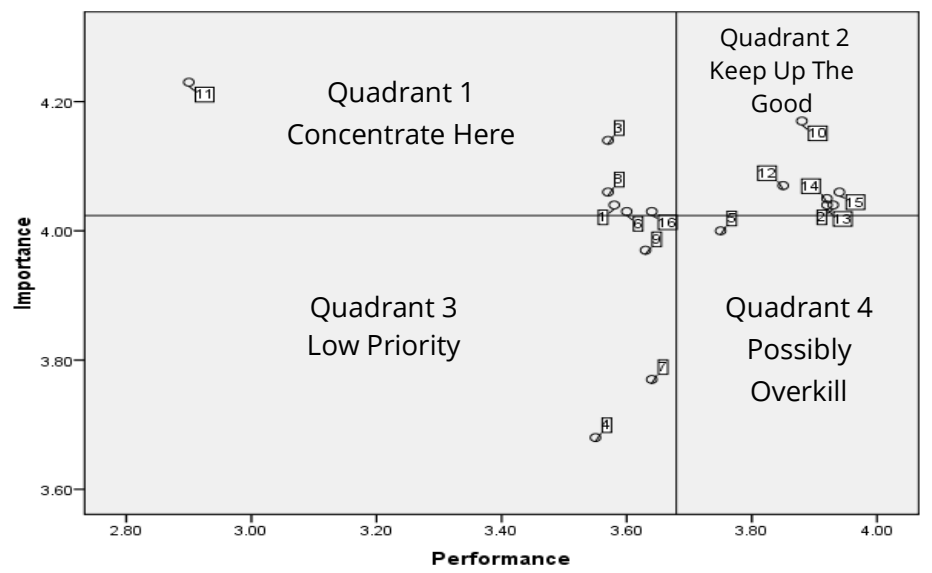

Figure 2

Cartesian Diagram for Measurement of performance and importance Marketing Agency Services.

Farmers' response to the performance of marketing institutions is quite high, because most attributes of institutional satisfaction are good enough. Of the 16 institutional service dimension attributes, there are 6 attributes that are classified as good, 6 attributes need to be improved, 3 other attributes are not a top priority, and 1 atrribute is possibly. The description of the quadrants as follows:

\section{Quadrant I (Concentrate Here)}

The first priority quadrant is an area that contains attributes with high or above average importance, but has a low or below average level of performance implementation. This quadrant contains attributes that are considered important by RGL citrus farmers but the performance of the production input institutions is still low. Thus the attributes that are in this quadrant need to be improved. The 6 attributes included in this area as follows convey information about the quality of RGL Citruss desired by consumers to farmers, accuracy of weighing, timely payment, readiness to serve, prioritizing farmers who have become customers and completeness of packing facilities.

\section{Quadrant II (Keep Up The Good Work)}

In this quadrant shows the basic elements or services that have been successfully implemented. For this reason, performance performance must be maintained. Considered very important and very satisfying. In the picture above there are attributes including: the ability to communicate from traders, the price received by farmers in accordance with the quality of fruit, openness and honesty in providing services, the existence of transportation tools used to market products, communication tools owned by traders (telephone and handphone), 
and equipment during the transaction process (calculator, books, pens, weighing tools, etc.).

\section{Quadrant III (Low Priority)}

Attributes in this quadrant according to farmers considered less important and less satisfying. Attributes included in this quadrant are: services provided quickly, precisely and always responsive to help RGL Citrus farmers, willingness to respect and serve and prioritize farmers 'needs, and the ability of traders to help provide solutions to farmers' complaints in marketing RGL Citruss. Farmers and traders in the purchase of Citruss do not pay too much attention to attributes related to the interests of farmers (fast service, prioritizing farmers' needs and providing solutions for farmers). Traders have an interest in making a profit, so their services in these attributes are relatively low according to farmers. From the farmer side, these attributes are considered unimportant because they realize that the trader will not always do that all the time, it is very dependent on the trader in the service of these attributes.

\section{Quadrant IV (Possible Overkill)}

The excessive priority quadrant shows aspects that are considered not so important but the implementation is excessive, this aspect has a $100 \%$ conformity level and that is almost or more than $100 \%$. It is considered less important by RGL Citrus farmers but the traders' performance is excessive. The attribute included in this excessive quadrant is good service. This is possible because the farmers consider that in general the traders' response in the service of buying Citruss is good enough. There are no Citruss that are not bought by merchants. But from the farmer side, this is something that is considered to be commonly done by traders, so that it becomes something that is relatively less important for farmers.

The service dimension in the form of direct evidence, guarantees and trustworthiness shows that the marketing agency services to farmers are already good (quadrant II). The high quality of marketing agency services is due to the ability of traders to communicate, the price received by farmers and good service. To improve the quality of marketing agency services, traders need to increase the dimensions of responsiveness (alertness in serving), assurance (on time to pay), tangibles (completeness of packing facilities) and empathy dimensions (prioritizing farmers who are already subscribed). In addition, the reliability dimension needs to be improved in relation to the accuracy of weighing and conveying information about the quality of RGL Citruss desired by consumers. Therefore it is necessary to improve the quality of merchant services in each service dimension in the form of trustworthiness, guarantees, direct evidence and empathy and responsiveness. 


\section{RGL Citrus Farmers Satisfaction with Marketing Institution Services}

In marketing institutions, the attribute that has the highest Weighted Score value is attribute number 2 (Communication ability from traders), number 13 (There is a transportation tool used to market products), 14 (Communication tools owned by traders (telephone and handphone) and 15 (Equipment during the transaction process (calculators, books, pens, weighing tools, etc.) So that this attribute is the attribute that contributes the highest satisfaction compared to other attributes of marketing agency services (Table 2).

Table 2. CSI calculation results for Marketing agency services

\begin{tabular}{lcccc}
\hline No & Importance mean & Weighted Factor & Performance mean & Weighted Score \\
\hline 1 & 4.04 & 6.28 & 3.58 & 0.22 \\
2 & 4.04 & 6.28 & 3.93 & 0.25 \\
3 & 4.14 & 6.43 & 3.57 & 0.23 \\
4 & 3.68 & 5.71 & 3.55 & 0.20 \\
5 & 4.00 & 6.21 & 3.75 & 0.23 \\
6 & 4.03 & 6.25 & 3.60 & 0.23 \\
7 & 3.77 & 5.86 & 3.64 & 0.21 \\
8 & 4.06 & 6.31 & 3.57 & 0.23 \\
9 & 3.97 & 6.17 & 3.63 & 0.22 \\
10 & 4.17 & 6.48 & 3.88 & 0.25 \\
11 & 4.23 & 6.57 & 2.90 & 0.19 \\
12 & 4.07 & 6.32 & 3.85 & 0.24 \\
13 & 4.04 & 6.28 & 3.92 & 0.25 \\
14 & 4.05 & 6.29 & 3.92 & 0.25 \\
15 & 4.06 & 6.31 & 3.94 & 0.25 \\
16 & 4.03 & 6.25 & 3.64 & 0.23 \\
\hline $\boldsymbol{\Sigma}$ & 64,38 & 100,00 & & \\
& Weighted Total (WT) & & & 3,68 \\
& CSI (\%) & & & \\
\hline
\end{tabular}

Source: Primary data, 2019

The farmer satisfaction index for marketing agency services by CSI calculation obtained a value of $73.58 \%$. Based on the satisfaction criteria using a linear numerical scale (Simamora, 2004), the level of satisfaction of citrus farmers to the services of marketing institutions is included in the satisfaction criteria which lie in the value range of $60 \%-80 \%$. This value indicates that overall RGL citrus farmers in Bermani Ulu Raya District are satisfied with the performance of marketing institutions. This indicates that the performance of merchant services in sales transactions with RGL citrus farmers is quite good and gives satisfaction to RGL citrus farmers. But on the other hand, there are still service attributes that need to be improved, namely attribute number 11 (timeliness in paying). Traders should focus 
on increasing attribute number 11 only because these attributes are considered to be able to provide more satisfaction to RGL Citrus farmers. The results of this study are in line with the opinion of Diyahya et al, (2016), marketing agencies must immediately improve service attributes that still have low performance so that their customers feel more satisfied and comfortable.

\section{Factors Affected Farmers' Satisfaction on Marketing Institution Services}

Multinomial regression results indicate that the model used is fit. By looking at the value of the Likelihood Ratio Test (table 3). This indicates that one or more independent variables significantly influence the dependent variable.

Table 3. Multinomial Logistic Regression Test Results.

\begin{tabular}{ll}
\hline \multicolumn{1}{c}{ Description } & Sig. \\
\hline Nagelkerke & .298 \\
Nilai likelihood ratio tests table $x^{2}$ & .008 \\
Korelasi pearson table $X^{2}$ & .940 \\
\hline Resourch: Data processing with SPSS &
\end{tabular}

The influence of all independent variables on the dependent variable is relatively small at $29.8 \%$. This value is confirmed in the partial test results, the effect of the independent variable on the dependent variable is only one of the 6 independent variables that have a significant effect (Table 4)

Table 4. Likelihood Ratio Tests

\begin{tabular}{lcccc}
\hline \multirow{2}{*}{ Effect } & Model Fitting Criteria & \multicolumn{2}{c}{ Likelihood Ratio Tests } \\
\cline { 2 - 5 } & $\begin{array}{c}-2 \text { log likelihood of } \\
\text { Reduced Model }\end{array}$ & Chi- Square & df & Sig \\
\hline Intercept & 1.086 E 2 & .000 & & \\
Age & 109.137 & .563 & 2 & .755 \\
FN & 110.144 & 1.570 & 2 & .456 \\
EDU & 109.719 & 1.144 & 2 & .564 \\
EXP & 114.397 & 5.823 & 2 & .054 \\
Land & 112.618 & 4.043 & 2 & .132 \\
PRC & 126.468 & 17.893 & 2 & $.000 *$ \\
\hline a Intercept & & & & \\
Note: * significantly different at a 0.05 level &
\end{tabular}

The characteristics of farmers do not have a significant effect on the level of satisfaction of farmers in their marketing institutions. The independent variable that influences is the quality of service of marketing institutions that is the price suitability received by farmers. Chi-square value of 17.793 shows a positive relationship. This means that the more appropriate the price received by farmers, the higher the RGL Citrus farmers will be. This variable influences presumably because the price received by citrus farmers is relatively in accordance with what is desired by RGL 
citrus farmers. In accordance with the theory put forward by Kotler and Keller (2009), prices are often set to satisfy demand or reflect the premium consumers are willing to pay for a product or service.

The results of the Wald test using SPSS can be seen in Table 4.

Table 4. Wald Test Results

\begin{tabular}{llrrrrrr}
\hline \multirow{2}{*}{ CSI } & Variabel & \multicolumn{1}{c}{ B } & $\begin{array}{c}\text { Std. } \\
\text { Error }\end{array}$ & \multicolumn{1}{l}{ Wald } & df & \multicolumn{1}{l}{ Sig. } & Exp(B) \\
\hline \multirow{4}{*}{ Less satisfied } & Intercept & -3.837 & 6.046 & .403 & 1 & .526 & \\
& AGE & -.008 & .078 & .011 & 1 & .916 & 0.68 \\
& EDU & .807 & .632 & 1.631 & 1 & .202 & 2.241 \\
& LAND & .065 & .352 & .034 & 1 & .853 & 1.067 \\
& EXP & .259 & .592 & .191 & 1 & .662 & 1.295 \\
& FN & 2.493 & 2.663 & .876 & 1 & .349 & 12.092 \\
& PRC (D1) & 18.770 & .721 & 676.820 & 1 & $.000 *$ & $1.42 \mathrm{E}+11$ \\
\hline \multirow{5}{*}{ Satisfied } & Intercept & -.931 & 5.842 & & 1 & & \\
& AGE & .011 & .074 & .025 & 1 & .873 & 1.011 \\
& EDU & .447 & .605 & .022 & 1 & .881 & 1.563 \\
& LAND & .181 & .341 & .544 & 1 & .461 & 1.199 \\
& EXP & -.202 & .565 & .282 & 1 & .595 & .817 \\
& FN & 2.140 & 2.600 & .128 & 1 & .721 & 8.498 \\
& PRC (D1) & 15.976 & .000 & .677 & 1 & .410 & $8.68 \mathrm{E}+09$ \\
\hline
\end{tabular}

Note: testing using SPSS against 117 RGL citrus farmers.

Reference category: Very Satisfied

The independent variable that affects farmers' satisfaction is the PRC (price suitability). The coefficient value of the price suitability variable is 18.770 . This means that the more incompatible with the price received by farmers 18.770 units, the tendency of farmers to feel less satisfied becomes one unit with the assumption that other variables are fixed. The positive sign $\mathrm{B}$ coefficient can be interpreted to be increasingly incompatible with the price received by RGL citrus farmers, the tendency of unsatisfied farmers to increase. If the level of satisfaction of farmers who are dissatisfied wants to increase their chances of being very satisfied, then the price suitability must be increased.

\section{CONCLUSIONS AND POLICY IMPLICATIONS}

\section{Conclusions}

The results of this study concluded as follows: 
1. The performance of marketing institutions is generally good. The quality of service that needs to be improved is the dimension of trustworthiness, assurance, direct evidence of empathy and responsiveness.

2. The satisfaction level of RGL citrus farmers marketing institutions are satisfied

3. The price factor has a positive effect on the satisfaction of RGL citrus farmers.

\section{Recommendations}

Marketing agencies should improve the quality of services, especially on the dimensions that are still lacking (weak). Improving the quality of marketing institutional services needs to be given more attention especially to the timeliness in payment and price matches.

\section{REFERENCES}

Aritonang. 2005. Kepuasan Pelanggan. Jakarta: PT Gramedia Pustaka Utama.

Diyahya, I., K.Sukiyono, dan R. Badrudin. 2016. Analisis Tingkat Kepuasan Petani Jagung terhadap Pelayanan Lembaga Pemasarannya di KecamatanLubuk Pinang Kabupaten Mukomuko. AGRISEP 16(1):45-58. DOI: https://doi.org/10.31186/agrisep.15.1.45-58

Fitriana, D. Florencia Y. K. O, Jati Utomo, D. H. Tanto. 2014. Pengukuran Kepuasan Kontraktor Terhadap Kinerja Klien Pada Proyek Konstruksi Swasta. Jurnal Teknik Sipil., 3(1) : 283 - 295.

Gama, I. G. M., R. Oktaviani, dan A. Rifin. 2016. Analisis Kepuasan Petani terhadap Penggunaan Pupuk Organik Pada Tanaman Padi. Jurnal Agro Ekonomi.34(2): 105-122. DOI: http://dx.doi.org/10.21082/jae.v34n2.2016.105-122.

Kotler dan Keller.2009. Manajemen Pemasaran. Jilid I. Edisi Ke 13. Jakarta. Erlangga.

Kumar, M., F.T. Kee, dan A.T. Manshoor. 2009. Determining the Relative Importance of Critical Factors in Delivering Service Quality of Banks. Managing Service Quality 19(2):212-232.

Martilla, John A., and John C. James. 1977. Importance-Performance Analysis. Journal of Marketing 41(1): 77. http://www.jstor.org/stable/1250495?origin=crossref.

Parasuraman, A, Valarie A Zeithaml, and Leonard L Berry. 1985. A Conceptual Model Service Its Quality and Implications for Future Research. Research Paper 49(4): 41-50.

Ramadhani, Paramitha Dwiasti.,Djoko Koestiono dan Silvana Maulidah. 2014. Analisis Tingkat Kepuasan Konsumen Terhadap Kinerja Pelayanan Pemasok Bunga Potong Krisan. Jurnal Habitat XXV (3).Hal:152.

Rusli, S. 2012. Pengantar IImu Kependudukan. LP3ES. Jakarta.

Sa'adah, I,. Mukson, dan Y, S, Ondho. 2019. Pengukuran Tingkat Kepuasan Peternak Dalam Pelayanan Inseminasi Buatan Menggunakan Analisis Customer 
Satisfaction Index (CSI) dan Importance Performance Analysis (IPA). JEPA.3 (3): 557-567. DOI https://doi.org/10.21776/ub.jepa.2019.004.01.20

Sangadji, E., dan Sopiah. 2013. Perilaku konsumen; pendekatan praktis disertai himpunan jurnal penelitian.Yogyakarta: Andi.

Siyamto, Yudi. 2015. Kualitas Pelayanan Bank Dengan Menggunakan Metode Importance Performace Analysis (IPA) dan Customer Satisfication Index (CSI) Terhadap Kepuasan Nasabah. Jurnal IImiah Ekonomi Islam 14(1): 6376. DOI: http://dx.doi.org/10.29040/jiei.v3i01.100

Sriliana, Idhia. 2012. Analisis Regresi Ordinal Untuk Mengetahui Faktor-Faktor Yang Mempengaruhi Kualitas Pelayanan Kesehatan Pada Komunitas Latino. Jurnla Ilmiah Gradien 8(2).802-808.

Subekti, Puji. 2014. Model Regresi Logistik Multinomial Untuk Menentukan Pilihan Sekolah Lanjutan Tingkat Atas Pada Siswa SMP. Cauchy 3(2): 91-98. DOI: http://dx.doi.org/10.18860/ca.v3i2.2577.

Suwantoro, B. 2010. Mengenal Jeruk Rimau Gerga Lebong Lebih Dekat. Balai Benih Hortikultura Rimbo Pengadang. Dinas Pertanian Dan Ketahanan Pangan Kabupaten Lebong.

Syukri, Siti Husna Ainu. 2014. Penerapan Customer Satisfaction Index (CSI) dan Analisis Gap Pada Kualitas Pelayanan Trans Jogja. Jurnal Ilmiah Teknik Industri. 13 (2).102-111. DOI: https://doi.org/10.23917/jiti.v13i2.618.

Tedjaningsih, Tenten, Suyudi, dan Hendar Nuryaman. 2018. Peran Kelembagaan dalam Pengembangan Agribisnis Mendong. Mimbar Agribisnis. 4(2): 210. https://jurnal.unigal.ac.id/index.php/mimbaragribisnis/article/view/898.

Tjiptono, Fandy dan Gregorius Chandra. 2011. Service, Quality and Satisfaction. Ketiga. Yogyakarta: Andi.

Umar, Husein. 2003. Metodologi Penelitian : Aplikasi dalam Pemasaran. Jakarta: Gramedia Pustaka Utama.

Utomo, D. A dan R. Nurmalina. 2011. Analisis Kepuasan dan Loyalitas Konsumen Prima Fresh Mart (Pendekatan Service Quality). Forum Agribisnis. 1(2): 132 150. DOI: https://doi.org/10.29244/fagb.1.2.132-150.

Widodo, Sanusi Mulyo, dan Joko Sutopo. 2018. Metode Customer Satisfaction Index ( CSI) Untuk Mengetahui Pola Kepuasan Pelanggan Pada E-Commerce Model Business to Customer. Jurnal Informatika UPGRIS 4(1): 38-45. DOI:10.26877/jiu.v4i1.2224.

Widyasari, Riska, Fembriati Erry Prasmatiwi, dan Suriaty Situmorang. 2014. Tingkat Kepuasan dan Loyalitas Konsumen Rumah Tangga dalam Mengonsumsi Bihun Jagung Di Bandar Lampung. JIIA 2(4): 382-89. DOI: http://dx.doi.org/10.23960/jiia.v2i4.382-389

Widyastuti, E dan N. Widiastuti. 2014. Analisis Kepuasan Petani Terhadap PelayananPenyuluh di Badan Pelaksana Penyuluhan dan Ketahanan Pangan Kabupaten Magelang Tahun 2014. Jurnal Riset Manajemen. 1(2): 148-147. DOI: https://doi.org/10.17509/image.v7i2.21657. 